STUDIA PRAWNO-EKONOMICZNE, T. CXVI, 2020

PL ISSN 0081-6841; e-ISSN 2450-8179

s. $65-79$

https://doi.org/10.26485/SPE/2020/116/4

\title{
Daria KOSTECKA-JURCZYK*
}

iD https://orcid.org/0000-0002-8404-7791

\section{OBOWIAZZEK NOTYFIKACJI ZAMIARU UTWORZENIA WSPÓLNEGO PRZEDSIĘBIORCY}

\begin{abstract}
Abstrakt
Przedmiot badań: Obowiązek notyfikacji zamiaru utworzenia wspólnego przedsiębiorcy Prezesowi UOKiK w świetle przepisów ustawy o ochronie konkurencji i konsumentów budzi liczne wątpliwości interpretacyjne, których nie można rozwiązać poprzez analogię do zasady przyjętej w rozporządzeniu Rady (WE) nr 139/2004. Oba rozwiązania istotnie się różnią zarówno w zakresie przedmiotowym, jak i podmiotowym.

Cel badawczy: Celem opracowania jest zbadanie konstrukcji prawnej i przesłanek obowiązku notyfikacji zamiaru utworzenia wspólnego przedsiębiorcy funkcjonującego w obu reżimach prawnych i ocena zasadności rozwiązań przyjętych w prawie polskim. W artykule przyjęto hipotezę, że obowiązek zgłoszeniowy w świetle przepisów ustawy o ochronie konkurencji i konsumentów (uokk) został sformułowany zbyt szeroko. Art. 13 ust. 2 pkt 3 uokk wymusza bowiem konieczność zgłoszenia wspólnych przedsiębiorców niestanowiących formy koncentracji i jest oderwany od obowiązującej w prawie unijnym zasady wspólnej kontroli wspólnego przedsiębiorcy, którego utworzenie stanowi stan faktyczny koncentracji.

Metoda badawcza: W celu weryfikacji przyjętej hipotezy badawczej zastosowano metodę analizy aktów prawnych oraz decyzji Komisji Europejskiej i Prezesa UOKiK. Do analizy rozporządzenia Rady (WE) nr 139/2004 oraz przepisów uokk wykorzystano także metodę formalno-dogmatyczną, a także metodę prawno-porównawczą.

Wyniki: W artykule wykazano, że funkcjonujący w prawie polskim obowiązek zgłoszeniowy jest sformułowany zbyt szeroko, gdyż obejmuje wspólnych przedsiębiorców, których utworzenie de facto nie spełnia przesłanek koncentracji.
\end{abstract}

Słowa kluczowe: koncentracje przedsiębiorców, prawo konkurencji, wspólny przedsiębiorca.

* Dr hab., Uniwersytet Wrocławski, Wydział Prawa, Administracji i Ekonomii; e-mail: daria. kostecka-jurczyk@uwr.edu.pl 


\section{Wprowadzenie}

Obowiązek zgłoszenia zamiaru utworzenia wspólnego przedsiębiorcy na gruncie ustawy o ochronie konkurencji i konsumentów budzi liczne wątpliwości ${ }^{1}$. Po pierwsze ustawa nie definiuje pojęcia wspólnego przedsiębiorcy i jedynie stanowi, że jego utworzenie należy kwalifikować jako stan faktyczny koncentracji. Ustawodawca przyjął założenie, że utworzenie każdego wspólnego przedsiębiorcy wymaga uzyskania zgody Prezesa UOKiK, ignorując funkcjonujący w prawie unijnym podział na wspólnego przedsiębiorcę pełno- i niepełnofunkcyjnego. Przesłanką zwalniającą z tego obowiązku jest jedynie osiągnięcie niższego obrotu niż wskazany w art. 13 ust. 1 uokk.

W efekcie obowiązek notyfikacji na gruncie uokk obejmuje transakcje, które mają niewielkie znaczenie dla polskiego rynku, lub takie, które mają ułatwiać koordynację zachowań rynkowych założycieli (np. cen, wielkości podaży, ofert itp.) i powinny być kwalifikowane jako porozumienia ograniczające konkurencję, których nie bada się w toku postępowania koncentracyjnego (np. nie ma możliwości zbadania koordynacji cen, która następuje po transakcji). Wydaje się, że obowiązek zgłoszeniowy powinien być uzależniony od charakteru wspólnego przedsiębiorcy, bowiem w praktyce przybiera on bardzo zróżnicowane formy.

\section{Pojęcie wspólnego przedsiębiorcy}

Wspólny przedsiębiorca stanowi formę współdziałania gospodarczego. Może zostać utworzony zarówno w sposób formalny, jak i nieformalny. W praktyce często wspólny przedsiębiorca powstaje, gdy co najmniej dwóch przedsiębiorców decyduje się podjąć wspólnie określoną działalność gospodarczą, której nie byliby w stanie realizować indywidualnie. Z tego też względu pojęcie wspólnego przedsiębiorcy jest różnie rozumiane. W szerokim ujęciu obejmuje ono umowę między co najmniej dwoma przedsiębiorcami m.in. w zakresie organizacji systemu produkcji, dystrybucji lub działalności badawczo-rozwojowej. Natomiast w wąskim ujęciu wspólny przedsiębiorca może oznaczać integrację działalności co najmniej dwóch przedsiębiorców² .

Ustawa z dnia 17.02.2007 r. o ochronie konkurencji i konsumentów (Dz.U., nr 50, poz. 331, t.j. Dz.U. z 2017 r., poz. 229 z późn. zm).

2 D. Kostecka-Jurczyk, Koncentracja $w$ formie wspólnego przedsiębiorstwa a ryzyko konkurencyjne w świetle prawa antymonopolowego, C.H. Beck, Warszawa 2017, s. 45 i nast. 
Celem utworzenia wspólnego przedsiębiorcy może być zapewnienie większej efektywności poprzez lepsze wykorzystanie zasobów. Ponadto wspólny przedsiębiorca może ułatwiać połączenie komplementarnych technologii lub know-how, ograniczanie „efektów zewnętrznych” i ryzyka dla założycieli. Innym powodem utworzenia wspólnego przedsiębiorcy może być podział zasobów lub poszerzenie bazy klientów. Utworzenie wspólnego przedsiębiorcy pozwala też na wzrost efektywności i uzyskanie korzyści skali. Może też ułatwić założycielom wejście na rynek, na który trudno byłoby im wejść odrębnie. Pojęcie to obejmuje zarówno transakcje koncentracji, jak i kooperacji w obszarze badawczo-rozwojowym, produkcji i dystrybucji ${ }^{3}$. Jednakże utworzenie wspólnego przedsiębiorcy nie zawsze przynosi pozytywne efekty. Może on bowiem ograniczyć lub nawet wykluczyć konkurencję między założycielami. Główny problem dotyczy tego, że spółki matki wspólnego przedsiębiorcy przestają konkurować ze sobą na rynku, jeśli to miałoby negatywnie wpłynąć na potencjalne korzyści, jakie zamierzają osiągnąć. Oznacza to, że utworzenie wspólnego przedsiębiorcy może być narzędziem wykorzystywanym przez założycieli do ograniczenia konkurencji na rynku. Wspólny przedsiębiorca może bowiem ułatwiać zawarcie porozumienia ograniczającego konkurencję lub stanowić agencję sprzedaży utworzoną w celu dystrybucji produktów założycieli po tych samych cenach albo wspólnego pozyskiwania zamówień, wykluczając rywalizację cenową między spółkami matkami.

$\mathrm{Z}$ uwagi na takie zróżnicowanie wspólnych przedsiębiorców w unijnym prawie konkurencji wyodrębniono wspólnego przedsiębiorcę pełno- i niepełnofunkcyjnego. Utworzenie pierwszego z nich stanowi stan faktyczny koncentracji (w świetle art. 3 ust. 4 rozporządzenia 139/20044). Drugi natomiast nie wchodzi aktualnie w zakres tego rozporządzenia i jest kontrolowany w oparciu o art. 101 TFUE dotyczący zakazu zawierania porozumień ograniczających konkurencję. W świetle art. 3 ust. 4 rozporządzenia 139/2004 tylko utworzenie wspólnego przedsiębiorcy na trwałych podstawach, pełniącego wszystkie funkcje autonomicznego przedsiębiorcy stanowi stan faktyczny koncentracji w rozumieniu art. 3 ust. 1 lit. b) rozporządzenia 139/2004. Taki wspólny przedsiębiorca musi być zorganizowany w sposób pozwalający realizować wszystkie funkcje, jakie

J. Kokkoris, H. Shelansky, EU Merger Control. A Legal and Economic Analysis, Oxford University Press 2014, s. 142.

4 Rozporządzenie Rady (WE) z dnia 20.01.2004, nr 139/2004 w sprawie kontroli koncentracji przedsiębiorstw (Dz. Urz. 2004, L 24, s. 1 - dalej jako: rozporządzenie 139/2004).

5 Przy projekcie rozporządzenia w sprawie kontroli koncentracji rozważano włączenie pewnych niepełnofunkcyjnych wspólnych przedsiębiorców w zakres tego rozporządzenia, ale ten pomysł nie został zrealizowany. 
wykonują inni przedsiębiorcy na rynku właściwym, i trwały, czyli perspektywa czasowa przewidziana dla jego działalności gospodarczej nie powinna być ograniczona.

Pełny zakres funkcji wspólnego przedsiębiorcy stanowi szczególny stan faktyczny objęty zakresem obowiązywania przepisów tego rozporządzenia (art. 3 ust. 4) ${ }^{6}$. Kluczowym warunkiem, jaki musi być spełniony dla potwierdzenia pełnego zakresu funkcji, jest wystąpienie kumulatywnych kryteriów: samodzielność (niezależność) operacyjna od założycieli, odpowiednie wyposażenie w zasoby, jak również trwałość prowadzenia działalności gospodarczej’ ${ }^{7}$ Jeśli przykładowo wspólny przedsiębiorca wykonuje określone funkcje w ramach działalności spółki dominującej i nie uczestniczy w transakcjach rynkowych jako samodzielny, odrębny przedsiębiorca ${ }^{8}$, wówczas stanowi on wyłącznie niepełnofunkcyjnego wspólnego przedsiębiorcę. Jeśli w toku działalności niepełnofunkcyjnego wspólnego przedsiębiorcy zmienią się wszystkie wymienione kluczowe elementy i będzie on wykonywał wszystkie funkcje niezależnego przedsiębiorcy na rynku właściwym, wówczas stanie się pełnofunkcyjnym wspólnym przedsiębiorcą i będzie podlegać obowiązkowi notyfikacji do Komisji Europejskiej (Komisja), o ile spełniona będzie przesłanka z art. 1 ust. 2 i 3 rozporządzenia 139/2004.

\section{Obowiązek zgłoszeniowy w świetle rozporządzenia Rady (WE) nr 139/2004}

W przepisach prawa konkurencji UE (art. 1 rozporządzenia 139/2004) obowiązek zgłoszeniowy obejmuje wyłącznie stan faktyczny koncentracji. Pojęcie to dotyczy wyłącznie transakcji, które prowadzą do trwałych zmian struktury uczestniczących przedsiębiorców i struktury rynku. Z tego powodu z rozporządzenia 139/2004 wyłączone są różne formy współdziałania gospodarczego, które nie są kwalifikowane jako operacja koncentracyjna w rozumieniu art. 3 rozporządzenia 139/2004

6 W celu uniknięcia posługiwania się różnymi pojęciami wykorzystywanymi w prawie krajowym i unijnym (np. przedsiębiorstwo i przedsiębiorca) w opracowaniu będzie używane pojęcie przedsiębiorcy, pomimo że w rozporządzeniu 139/2004 ustawodawca unijny posługuje się pojęciem przedsiębiorstwa. Na temat różnic pojęciowych „przedsiębiorcy” w prawie krajowym i „przedsiębiorstwa” w prawie unijnym zob. G. Materna, Pojęcie przedsiębiorcy w polskim i europejskim prawie konkurencji, Wolters Kluwer, Warszawa 2009, s. 44-70; zob. też D. Kostecka-Jurczyk, Koncentracja..., s. 6 i nast.

7 D. Kostecka-Jurczyk, Kryterium petnego zakresu funkcji $w$ analizie koncentracji $w$ formie joint venture, Finanse, Rynki Finansowe, Ubezpieczenia 2016/82 (4), s. 507-517.

8 Skonsolidowane obwieszczenie Komisji dotyczące kwestii jurysdykcyjnych na mocy rozporządzenia Rady (WE) nr 139/2004 w sprawie kontroli koncentracji przedsiębiorstw, Dz. Urz. 2008, Nr C 95, s. 1, pkt 95 i 98 (dalej jako: obwieszczenie jurysdykcyjne). 
i których celem lub skutkiem jest wyłącznie koordynacja zachowań rynkowych niezależnych względem siebie przedsiębiorców. Taka koordynacja wchodzi w zakres art. 101 TFUE, a nie w zakres przepisów o kontroli koncentracji. Obowiązek notyfikacji obejmuje tylko operacje koncentracyjne, tj. utworzenie pełnofunkcyjnego wspólnego przedsiębiorcy oraz przejęcie kontroli nad wspólnym przedsiębiorcą ${ }^{9}$.

W decyzjach dotyczących utworzenia wspólnego przedsiębiorcy Komisja podejmuje dwustopniowe badanie: po pierwsze sprawdza, czy spółki matki mają wspólną kontrolę nad wspólnym przedsiębiorcą stosownie do art. 3 ust. 1 lit. b) rozporządzenia 139/2004. Po drugie bada, czy wspólne przedsiębiorstwo ma charakter pełnofunkcyjny. Taką praktykę należy ocenić pozytywnie, gdyż 3 ust. 4 rozporządzenia 139/2004 nie dotyczy odrębnej koncentracji, ale wspólnej kontroli w rozumieniu art. 3 ust. 1 lit. b) rozporządzenia 139/2004 ${ }^{10}$. Cecha pełnego zakresu funkcji, która jest wymieniona w pierwszym zdaniu tego przepisu, stanowi dodatkową przesłankę traktowania wspólnego przedsiębiorcy jako koncentracji w rozumieniu przepisów rozporządzenia 139/2004. Hipoteza tego przepisu wyraźnie wskazuje na stan faktyczny koncentracji poprzez przejęcie kontroli (art. 3 ust. 1 lit. b) rozporządzenia 139/2004 i może obejmować przypadek przejęcia wspólnej kontroli, gdyż niezbędne jest, aby spółki matki wspólnie kontrolowały wspólnego przedsiębiorcę. Jeżeli art. 3 ust. 4 rozporządzenia 139/2004 obejmowałby odrębny stan faktyczny koncentracji, wówczas nie tylko ust. 1 lit. b) dotyczyłby przejęcia kontroli, ale cały przepis art. 3 ust. 1 rozporządzenia 139/2004. Art. 3 ust. 4 wyjaśnia, że utworzenie wspólnego przedsiębiorcy generuje wspólną kontrolę, przy czym dla zastosowania przepisów rozporządzenia 139/04 musi mieć on charakter pełnofunkcyjny. Zdaniem Komisji przejęcie lub istnienie wspólnej kontroli przez spółki matki powinno zostać zbadane /i potwierdzone/ wraz z analizą pełnego zakresu funkcji ${ }^{11}$. Istotną przesłanką, której spełnienie rodzi obowiązek zgłoszeniowy, jest unijny wymiar koncentracji.

9 W obwieszczeniu jurysdykcyjnym Komisja po raz pierwszy wyjaśniła, że koncentracja następuje, gdy działalność istniejącego niepełnofunkcyjnego wspólnego przedsiębiorcy zmienia się tak, że staje się ono pełnofunkcyjnym wspólnym przedsiębiorcą w rozumieniu art. 3 ust. 4 rozporządzenia 139/04. Komisja wskazała także, że koncentrację mogą stanowić również procesy, w wyniku których następuje zmiana działalności wspólnego przedsiębiorcy. Należy również zwrócić uwagę, że wymienione kryteria pełnofunkcyjności mogą oznaczać, że działalność wspólnego przedsiębiorcy nie zostaje ograniczona, podejmuje on działalność pomocniczą dla spółek matek, ale w przyszłości może stać się niezależnym przedsiębiorcą i trwale funkcjonować na rynku. Wówczas powstanie obowiązek jego notyfikacji.

10 A. Wenz, Der Begriff der Kontrolle im europäischen und deutschen Fusionsrecht, Marburg 2007, s. 164.

11 Decyzja Komisji z dnia 3.10.2008 w sprawie COMP/M.5241 - American Express/Fortis/Alpha Card, pkt 1, 16. 


\section{Unijny vs krajowy wymiar koncentracji}

W Preambule rozporządzenia 139/2004 wskazano, że koncentracja powinna być definiowana $\mathrm{w}$ taki sposób, aby objąć jej zakresem pojęciowym operacje skutkujące trwałą zmianą w strukturze kontroli uczestniczącego przedsiębiorcy i w strukturze rynku ${ }^{12}$. To zdanie wskazuje, że po pierwsze postępowanie koncentracyjne ma na celu kontrolę zmian w strukturze rynku. Po drugie, aby osiągnąć ten cel, każda trwała zmiana w kontroli uczestniczącego przedsiębiorcy powinna być zbadana $\mathrm{w}$ tym postępowaniu. To zostało odzwierciedlone $\mathrm{w}$ art. 3 ust. 1 lit. b) rozporządzenia 139/04, w którym przejęcie przez jedną lub więcej osób pośredniej lub bezpośredniej kontroli nad całym lub częścią jednego lub więcej innych przedsiębiorców jest definiowane jako zdarzenie (transakcja) wymagające notyfikacji, jeżeli ma ona wymiar unijny. Rozporządzenie 139/2004 ma bowiem zastosowanie tylko w przypadku koncentracji o wymiarze unijnym, czyli gdy obrót przedsiębiorców uczestniczących w transakcji przekroczy jeden z poniższych progów:

- łączny światowy obrót wszystkich zainteresowanych przedsiębiorców przekracza 5 mld euro,

- łączny obrót w UE w każdym z przynajmniej dwóch zainteresowanych przedsiębiorców przekracza 250 mln euro, chyba że każdy z zainteresowanych przedsiębiorców uzyskuje więcej niż dwie trzecie łącznego obrotu przypadającego na UE w tym samym państwie członkowskim (art. 1 ust. 2 rozporządzenia 139/04).

Jeżeli powyższa wielkość obrotu nie zostanie osiągnięta, koncentrację należy notyfikować krajowemu organowi ochrony konkurencji w państwie członkowskim, w którym realizowany jest ten obrót. Wynika to z faktu, że koncentracja może mieć znaczenie dla konkurencji w tym państwie. Należy zwrócić jednak uwagę, że obowiązek notyfikacji do Komisji Europejskiej powstaje niezależnie od wysokości obrotu będącej podstawą obowiązku notyfikacji w państwie członkowskim w świetle prawa krajowego tego państwa.

W świetle uokk obowiązek notyfikacji powstaje przy zdecydowanie niższych progach obrotu. Mianowicie, jeżeli łączny światowy obrót przedsiębiorców uczestniczących w koncentracji w roku obrotowym poprzedzającym rok zgłoszenia przekracza równowartość 1 mld euro lub łączny obrót na terytorium Rzeczypospolitej Polskiej przedsiębiorców uczestniczących w koncentracji w roku obrotowym poprzedzającym rok zgłoszenia przekracza równowartość $50 \mathrm{mln}$

12 Rozporządzenie 139/2004, Preambuła pkt 20. 
euro. W przeciwieństwie do rozporządzenia 139/2004 na gruncie uokk powstanie obowiązku notyfikacji wspólnego przedsiębiorcy nie jest uwarunkowane przejęciem kontroli nad nim.

W świetle prawa konkurencji UE dla powstania obowiązku notyfikacji obok unijnego wymiaru w rozumieniu art. 1 rozporządzenia 139/2004 musi nastąpić stan faktyczny koncentracji w rozumieniu art. 3 tego rozporządzenia. Ma ono zastosowanie w przypadkach, w których uczestniczący w koncentracji przedsiębiorcy osiągają określony obrót tak na rynku światowym, jak i unijnym (art. 1 rozporządzenia 139/2004). Rozstrzygający jest przy tym łączny obrót przedsiębiorców uczestniczących w koncentracji, biorąc pod uwagę geograficzny zakres ich działalności. Chociaż dane dotyczące wielkości obrotu nie prowadzą do żadnych konkretnych wniosków co do skutków koncentracji z punktu widzenia prawa konkurencji - taki formalny sposób określenia zakresu stosowania prawa kontroli koncentracji UE uzasadnia potrzeba pewności prawnej. Wyższe obroty dają obraz pozycji rynkowej i znaczenia uczestniczących przedsiębiorców na rynku światowym, a przekroczenie określonych progów pozwala domniemywać zakłócenia konkurencji. Przy ustaleniu zakresu stosowania rozporządzenia 139/04 rozstrzygający jest światowy obrót także, jeśli działalność gospodarcza przedsiębiorców uczestniczących w transakcji rzeczywiście będzie wykonywana w ramach i/lub poza rynkiem wewnętrznym. Dla zobrazowania można wskazać następującą sytuację, w której zastosowanie miało rozporządzenie 139/04: przedsiębiorca posiadający siedzibę w państwie trzecim wraz z innym przedsiębiorcą, który posiadał siedzibę w EOG, podjął decyzję o utworzeniu wspólnego przedsiębiorcy. Rozporządzenie 139/04 obejmuje także przypadki, gdy przedsiębiorcy posiadający siedzibę w UE tworzą wspólnego przedsiębiorcę, który ma być obecny wyłącznie na rynku państwa trzeciego.

Także koncentracje dokonywane za granicą, w państwach trzecich, tj. gdy wszyscy uczestniczący przedsiębiorcy posiadają siedzibę poza EOG i wspólny przedsiębiorca będzie prowadził działalność wyłącznie w państwie trzecim, mogą wywierać znaczne skutki dla rynku wewnętrznego i mogą być kontrolowane na podstawie rozporządzenia 139/04. Rozporządzenie to jest stosowane niezależnie od tego, w którym państwie uczestniczący w koncentracji przedsiębiorcy posiadają swoją siedzibę i gdzie znajdują się jego zakłady produkcyjne oraz centrala, jeśli planowana koncentracja wywiera znaczne skutki na rynku wewnętrznym UE. Obejmuje ono więc także takie przypadki, gdy w koncentracji uczestniczą wyłącznie przedsiębiorcy posiadający siedzibę w państwie trzecim. Muszą wówczas być spełnione określone przesłanki. W świetle pkt 10 preambuły rozporządzenia 139/2004 zamiar koncentracji jest badany w oparciu o przepisy 
rozporządzenia 139/2004 w sytuacji, gdy łączny obrót uczestniczących przedsiębiorców przekracza próg określony w art. 1 ust. 2 lub 3 rozporządzenia 139/2004 i przedsiębiorcy w znacznym zakresie prowadzą działalność na rynku UE.

W zakres rozporządzenia 139/2004 wchodzi bowiem koncentracja, która wywiera skutki na rynku wewnętrznym. Wynika to z przyjętej w rozporządzeniu 139/2004 zasady skutku, która została potwierdzona przez TSUE jako przesłanka określenia zakresu stosowania rozporządzenia 139/2004. Koncentracja wchodzi w zakres rozporządzenia 139/2004 wówczas, gdy można zauważyć jej pośrednie, istotne i przewidywalne skutki dla rynku wewnętrznego. Jeśli takie skutki nastąpią, rozporządzenie 139/2004 ma zastosowanie nawet w przypadku koncentracji realizowanych w państwach trzecich ${ }^{13}$. Tym samym w przypadku transakcji, w których uczestnikami są tylko przedsiębiorcy z państw trzecich i które tylko tam będą realizowane - rozporządzenie 139/04 ma zastosowanie, o ile transakcja wywiera wpływ na konkurencję na rynku wewnętrznym i spełniona jest przesłanka wymiaru unijnego ${ }^{14}$.

Zasada skutku obowiązuje także na gruncie prawa polskiego. Zgodnie z art. 1 ust. 2 uokk zakres przedmiotowy ustawy obejmuje koncentracje, które wywołują skutki antykonkurencyjne na obszarze Rzeczypospolitej Polskiej. Oznacza to, że jeżeli przedsiębiorcy zamierzają utworzyć wspólnego przedsiębiorcę, który poprzez swoje zachowania może spowodować takie skutki na polskim rynku i spełniona jest przesłanka z art. 13 ust. 1 pkt 1 i 2 uokk, wówczas transakcję należy notyfikować Prezesowi UOKiK.

\section{Różnice między polskim i unijnym reżimem kontroli koncentracji}

Istotna różnica między polskim i unijnym prawem kontroli koncentracji, jak już wskazano powyżej, dotyczy charakteru samej transakcji. W świetle rozporządzenia 139/2004 dla powstania obowiązku zgłoszenia zamiaru utworzenia wspólnego przedsiębiorcy obok wspomnianej przesłanki osiągnięcia określonego progu obrotu, wspólny przedsiębiorca musi być pełnofunkcyjny i jego utworzenie musi spełniać przesłanki stanu faktycznego koncentracji. Następuje to w sytuacji, gdy założyciele przejmują wspólną kontrolę nad takim przedsiębiorcą. W świetle polskiej uokk obowiązek zgłoszeniowy powstaje niezależnie od stanu faktycznego koncentracji. Oznacza to, że ustawodawca nie wymaga,

13 Wyrok SPI z dnia 25.03.1999 w sprawie T-102/96 Gencor/Lornho, Zb. Orz. 1999, s. II-753, ECLI:EU:T:1997:82, pkt 89.

14 To wynika ze sformułowanej w prawie międzynarodowym zasady skutku. 
aby wspólny przedsiębiorca podlegał wspólnej kontroli spółek matek. W świetle Wyjaśnień w sprawie kryteriów i procedury zgłaszania koncentracji Prezesowi UOKiK obowiązek zgłoszenia dotyczy także typowo kooperacyjnych wspólnych przedsiębiorców nawet w sytuacji, gdy założyciele nie będą ich kontrolować ${ }^{15}$.

Na gruncie uokk obowiązek zgłoszeniowy powstaje, jeżeli spełnione są dwie przesłanki: a) osiągnięcie poziomu obrotu określonego w art. 13 ust. 1 uokk, b) utworzenie przedsiębiorcy przez co najmniej dwóch przedsiębiorców. Jak już wspomniano na początku opracowania, w uokk nie wyodrębniono poszczególnych typów wspólnych przedsiębiorców, co oznacza, że każdy przypadek utworzenia wspólnego przedsiębiorcy należy notyfikować, jeżeli spełniona jest przesłanka $\mathrm{z}$ art. 13 ust. 1 uokk $^{16}$. W Wyjaśnieniach prezentowany jest pogląd, że już samo utworzenie wspólnego przedsiębiorcy stanowiącego nowy podmiot $\mathrm{w}$ sensie prawnym, nawet jeżeli nie jest on niezależny gospodarczo od założycieli, podlega reżimowi art. 13 uokk bez względu na to, czy spełnia przesłanki trwałości ${ }^{17}$. Taki przypadek wspólnego przedsiębiorcy w zasadzie stanowi formę kooperacji założycieli i (lub) wspólnego przedsiębiorcy oraz wspólnego przedsiębiorcy i co najmniej jednego z założycieli. Należy więc kwalifikować go jako porozumienie i oceniać w oparciu o art. 6 uokk.

Pomimo to, w Wyjaśnieniach wyrażono pogląd, że Prezes UOKiK prowadzi postępowanie w sprawie koncentracji także w stosunku do wspólnych przedsiębiorców niewykonujących ,wszystkich funkcji samodzielnego podmiotu gospodarczego"18. Oznacza to, że nadzorowi Prezesa UOKiK, zupełnie niepotrzebnie, podlegają wszystkie przypadki utworzenia wspólnego przedsiębiorcy bez względu na jego charakter gospodarczy i zakres powiązań z założycielami.

W praktyce większość zgłaszanych Prezesowi UOKiK wspólnych przedsiębiorców ma charakter kooperacyjny i nie stanowi formy koncentracji ${ }^{19}$, a objęcie ich obowiązkiem notyfikacyjnym nie ma uzasadnienia. Należy też zwrócić uwagę na fakt, że utworzenie takich właśnie niekoncentracyjnych wspólnych przedsiębiorców

5 Urząd Ochrony Konkurencji i Konsumentów, Warszawa 2015, https://uokik.gov.pl/download. php?id=1269; stan na 28.09.2019 r. W Wyjaśnieniach wyraźnie wskazano, że utworzenie wspólnego przedsiębiorcy, który nie posiada cech trwałości w rozumieniu przepisów rozporządzenia nr 139/2004, również podlega obowiązkowi notyfikacji do Prezesa UOKiK (pkt 2.4).

16 Ibidem, pkt 2.4.

17 Ibidem.

18 Przykładowo decyzja w sprawie kooperacyjnego wspólnego przedsiębiorcy - decyzja Prezesa UOKiK z dnia 14.09.2004, DOK-91/2004 w sprawie Schneider Toshiba Inverter SAS z siedziba w Pacy sur Eure, Francja i VA TECH ELIN EBG Elektronik GmbH \& Co. z siedziba w Wiedniu (utworzenie wspólnego przedsiębiorcy: STI ELIN Inverters GmbH z siedziba w Wiedniu).

19 D. Kostecka-Jurczyk, Koncentracja..., s. 85. 
może sprzyjać zakłóceniu konkurencji w rozumieniu art. 6 ust. 1 uokk ${ }^{20}$. Przepis ten zawiera zakaz porozumień ograniczających konkurencję (cenowych, kontyngentowych, podziałowych, wiązanych, dyskryminujących, ograniczających dostęp do rynku lub eliminujących z rynku przedsiębiorców i przetargowych). Ściganie przedsiębiorców naruszających art. 6 uokk następuje po zawarciu porozumienia. Przepisy ustawy nie przewidują możliwości weryfikacji ewentualnego naruszenia art. $6 \mathrm{w}$ toku postępowania koncentracyjnego. Inaczej jest w unijnym rozporządzeniu 139/2004, które w art. 2 ust. 4 i 5 wyraźnie stanowi, że koordynacja zachowań rynkowych założycieli wspólnego przedsiębiorcy będzie badana w postępowaniu koncentracyjnym w oparciu o art. 101 TFUE. Art. 18 uokk ogranicza badanie koncentracji do zakłócenia konkurencji „,W szczególności poprzez powstanie lub umocnienie pozycji dominującej". W sytuacji gdy koncentracja nie powoduje ograniczenia konkurencji, Prezes UOKiK wydaje zgodę na dokonanie transakcji. W pewnych przypadkach może wydać zgodę warunkową, nakładając na przedsiębiorców zobowiązania mające zapewnić, że nie dojdzie do zakłócenia konkurencji po dokonaniu transakcji (art. 19 ust. 1 i 2 uokk). W ustawie nie przewidziano jednak wprost możliwości zastosowania art. $6 \mathrm{w}$ postępowaniu koncentracyjnym. Biorąc pod uwagę fakt, że jest to zupełnie odrębne postępowanie, należy uznać, że w obecnym stanie prawnym Prezes UOKiK nie może badać naruszenia art. 6 uokk, wydając decyzję w sprawie koncentracji. Art. 18 i art. 20 ust. 1 uokk wskazuje jedynie, że w postępowaniu koncentracyjnym Prezes UOKiK sprawdza, czy w wyniku transakcji nie dojdzie do istotnego ograniczenia konkurencji, co nie oznacza możliwości wszczęcia jednoczesnego postępowania w oparciu o art. 6 uokk $^{21}$. Istotne zakłócenie konkurencji w rozumieniu art. 18 i art. 20 ust. 1 uokk oznacza przede wszystkim ,powstanie lub umocnienie pozycji dominującej”.

Analizując obowiązek notyfikacyjny, należy zwrócić uwagę także na art. 13 ust. 2 pkt 3 uokk. Przepis ten określa istotną dodatkową przesłankę, która powinna ograniczać obowiązek zgłoszeniowy do wspólnego przedsiębiorcy będącego formą koncentracji. Wskazano w nim bowiem, że wspólny przedsiębiorca jest tworzony przez przedsiębiorców. Zatem w przypadku gdy tylko jeden przedsiębiorca tworzy spółkę zależną, w której jest on założycielem posiadającym 100\% akcji (udziałów), nie następuje stan faktyczny koncentracji i nie można wówczas mówić o wspólnym przedsiębiorcy. Jeżeli nie zostaje spełniona przesłanka wspólnej kontroli, wspólny przedsiębiorca nie powinien podlegać obowiązkowi

20 Zob. K. Kohutek, M. Sieradzka, Ustawa o ochronie konkurencji i konsumentów. Komentarz, Wolters Kluwer business, Warszawa 2014, s. 485-486.

21 Zob. R. Stankiewicz, Nadzór administracyjnoprawny jako forma relacji określająca oddziaływanie państwa na procesy koncentracji przedsiębiorców, Studia Iuridica 2006/XLV, s. 199-203. 
notyfikacji. W świetle Wyjaśnień, art. 13 ust. 2 pkt 3 uokk nie pozwala jednak na wyłączenie takiego wspólnego przedsiębiorcy z obowiązku notyfikacji ${ }^{22}$. Oznacza to, że obowiązek notyfikacji transakcji powstaje także w przypadku przejęcia pakietów mniejszościowych w kapitale zakładowym wspólnego przedsiębiorcy, jeżeli przejmującym jest przedsiębiorca w rozumieniu art. 4 ust. 1 uokk ${ }^{23}$. Takie sformułowanie przyjęte w Wyjaśnieniach stanowi zupełnie nieuzasadnione rozszerzenie obowiązku notyfikacyjnego na nabycie pakietów mniejszościowych, ponieważ uokk nie wymaga zgłoszenia Prezesowi UOKiK nabycia pakietów mniejszościowych ${ }^{24}$.

Uokk wyłączyła bowiem z obowiązku zgłoszenia transakcje polegające na nabyciu lub objęciu mniejszościowych pakietów akcji (udziałów). Zasada ta nie obowiązuje jednak w przypadku utworzenia wspólnego przedsiębiorcy. Zgodnie z Wyjaśnieniami Prezesa UOKiK obowiązek notyfikacji powstaje nawet w przypadku nabycia (objęcia) jednej akcji (udziału) wspólnego przedsiębiorcy. W Wyjaśnieniach ignorowany jest zatem przyjęty w rozporządzeniu 139/2004 wymóg wspólnej kontroli. Wskazano w nich, że obowiązek notyfikacji zamiaru utworzenia wspólnego przedsiębiorcy obejmuje nawet takiego wspólnego przedsiębiorcę, który podlega wyłącznej kontroli tylko jednego przedsiębiorcy, w tym takiego, na który tylko jeden z założycieli posiada decydujący wpływ, a pozostali posiadają mniejszościowe udziały (akcje) nieuprawniające do kontroli spółki. Takie podejście zaprzecza idei wspólnej kontroli, bowiem wspólny przedsiębiorca nie może podlegać wyłącznej kontroli jednego z założycieli. Istotą wspólnego przedsiębiorcy w prawie unijnym jest bowiem kontrola wspólna. Takie podejście zaprzecza też samej idei wspólnego przedsiębiorcy i treści art. 13 ust. 2 pkt 3 uokk. Zgodnie z literalnym brzmieniem tego przepisu wspólny

22 Wyjaśnienia w sprawie kryteriów i procedury zgłaszania koncentracji Prezesowi UOKiK, op. cit., pkt 2.4 .

23 D. Kostecka-Jurczyk, Kontrola koncentracji a nabywanie pakietów mniejszościowych, PPH 2015/12, s. 53-58.

24 Obowiązek taki przewidywał art. 12 ust. 3 pkt 1 nieobowiązującej już ustawy z dnia 15.12.2000 r. o ochronie konkurencji i konsumentów (Dz.U. WE z 2000 r., nr 122, poz. 1319 z późn. zm). Zob. przykładowo decyzję Prezesa UOKiK z dnia 14.08.2002 nr RKT-41/2002 w sprawie Gmina Dąbrowa Górnicza, ,,Nemo-Investment” Sp. z o.o. w Czeladzi i „NEMO-WODNY ŚWIAT Dąbrowa Górnicza” Sp. z o.o. w Dąbrowie Górniczej; decyzja Prezesa UOKiK z dnia 30.10.2003 nr DDF-37/2003 w sprawie Orbis S.A. z siedzibq w Warszawie i Consulting Plus Sp. z o.o. z siedzibq w Warszawie (utworzenie wspólnego przedsiębiorcy: Conbis Sp. z o.o. z siedziba w Warszawie); decyzja Prezesa UOKiK z dnia 14.05.2007 nr RKR-44/2007 w sprawie APIA Real Estate S.a.r.l. z siedziba w Luksemburgu i Atrium Residence Sp. z o.o. z siedziba w Krakowie. 
przedsiębiorca jest tworzony przez przedsiębiorców. Ustawodawca wskazuje wprost, że wspólnego przedsiębiorcę tworzą inni niezależni przedsiębiorcy. Z tego względu należałoby zweryfikować także Wyjaśnienia w sprawie kryteriów i procedury zgłaszania zamiaru koncentracji Prezesowi UOKiK i ograniczyć wykładnię obowiązku notyfikacji zamiaru utworzenia wspólnego przedsiębiorcy na gruncie uokk do stanu faktycznego koncentracji.

Powyższe rozważania skłaniają zatem do pytania, czy nie należałoby rozważyć rozróżnienia w uokk wspólnych przedsiębiorców pełno- i niepełnofunkcyjnych na wzór rozporządzenia $\mathrm{nr}$ 139/200425. Aktualnie obowiązek zgłoszenia na gruncie uokk jest zbyt szeroki. Obowiązkiem tym objęci są zatem wspólni przedsiębiorcy, których celem jest koordynacja zachowań rynkowych założycieli i wspólni przedsiębiorcy zależni od jednego z założycieli, niepodlegający wspólnej kontroli. Obowiązek zgłoszeniowy dotyczy również notyfikacji transakcji przejęcia pakietów mniejszościowych w kapitale zakładowym. Art. 13 ust. 2 pkt 3 uokk nie pozwala na wyłączenie spod obowiązku notyfikacji żadnego ze wspólnych przedsiębiorców. Praktycznie jedynym kryterium decydującym o powstaniu obowiązku zgłoszeniowego jest art. 13 ust. 2 pkt $3 \mathrm{w}$ zw. $\mathrm{z}$ art. 13 ust. 1 pkt 1 i 2. Jeżeli spełnione są przesłanki określone w tych przepisach, nie ma żadnej możliwości wyłączenia utworzenia wspólnego przedsiębiorcy z obowiązku zgłoszeniowego.

\section{Wnioski}

Obecny reżim prawny, któremu podlegają wspólni przedsiębiorcy, odbiega od rozwiązań funkcjonujących na gruncie prawa unijnego i nie ma związku z ich ekonomicznym znaczeniem dla założycieli. Konstrukcja wspólnego przedsiębiorcy w świetle uokk wydaje się być nadmiernie uproszczona i z pewnością nie sprzyja ekonomicznemu podejściu Prezesa UOKiK w zakresie kwalifikacji i oceny wspólnych przedsiębiorców jako formy koncentracji. W świetle uokk wszystkie typy wspólnych przedsiębiorców zarówno tych tworzonych w celu koncentracji, jak i koordynacji zachowań rynkowych założycieli spełniające progi ilościowe

\footnotetext{
Zob. T. Skoczny, w: Ustawa o ochronie konkurencji i konsumentów, Komentarz, C.H. Beck, Warszawa 2014, s. 615; R. Stankiewicz, Joint ventures $w$ prawie antymonopolowym, PPH 2007/8, s. 15-16; S. Gronowski, Uokk. Komentarz, drugie wydanie, Warszawa 1999, s. 319; J. Lenart, T. Kaczyńska, Kiedy utworzenie nowej spółki nie będzie kwalifikowane jako utworzenie nowego przedsiębiorcy (joint venture)? Praktyczne rozważania dotyczace problematyki joint venture w polskim prawie konkurencji, iKAR 2016/1 (5), s. 36-51; S. Dudzik, Kontrola koncentracji w świetle ostatnich zmian ustawowych, iKAR 2015/2 (4), s. 27-28, 41.
} 
określone w art. 13 ust. 1 uokk podlegają obowiązkowi notyfikacji Prezesowi $\mathrm{UOKiK}^{26}$. Ustawodawca nie ograniczył art. 13 ust. 2 pkt 3 do koncentracyjnych (pełnofunkcyjnych) wspólnych przedsiębiorców.

Należy zatem rozważyć zmianę art. 13 ust. 2 pkt 3 uokk i zrezygnować z zasady kontrolowania utworzenia wszystkich typów wspólnych przedsiębiorców. Obowiązek notyfikacji zamiaru utworzenia wspólnego przedsiębiorcy należy ograniczyć jedynie do stanu faktycznego koncentracji. Dzięki temu powstałoby przejrzyste narzędzie podziału wspólnych przedsiębiorców na takich, których utworzenie stanowi stan faktyczny koncentracji, i takich, których należy oceniać w odrębnym postępowaniu w oparciu o art. 6 i 8 uokik. Takie rozwiązanie nie tylko zapewniłoby przejrzystość przepisów o kontroli koncentracji, ale też mogłoby ułatwić Prezesowi UOKiK publikowanie pełnych decyzji (wraz z uzasadnieniem) w związku z mniejszą ilością wpływających wniosków. Aktualnie trudno jest badać zastosowanie przepisów o kontroli koncentracji do wspólnych przedsiębiorców z uwagi na fakt, że w wielu decyzjach Prezes UOKiK publikuje tylko sentencję. W samym tyko 2018 r. na 229 decyzji wydanych w sprawach koncentracji przedsiębiorców 81 dotyczyło utworzenia wspólnego przedsiębiorcy, przy czym tylko jedna decyzja zawierała szczegółowe uzasadnienie ${ }^{27}$.

Warto rozważyć także weryfikację Wyjaśnień w sprawie kryteriów i procedury zgłaszania koncentracji Prezesowi UOKiK w zakresie obowiązku notyfikacji nabycia mniejszościowych pakietów akcji (udziałów) wspólnego przedsiębiorcy, które nie wpływają na strukturę kontroli tego przedsiębiorcy. Na gruncie uokk nie ma obowiązku zgłoszenia transakcji polegających na nabyciu lub objęciu mniejszościowych pakietów akcji (udziałów). Zatem wskazany w Wyjaśnieniach obowiązek ich notyfikacji w przypadkach dotyczących wspólnego przedsiębiorcy budzi uzasadnione wątpliwości i skłania do wniosku, że należy rozważyć zmiany także w tym zakresie.

26 Taki pogląd wyraził Prezes UOKiK w Wyjaśnieniach w sprawie kryteriów i procedury zgłaszania koncentracji Prezesowi UOKiK, op. cit., s. 20-21, pkt 2.4.

27 Decyzja Prezesa UOKiK z dnia 22.06.2018 nr DKK-102/2018 Faurecia Exhaust International S.A.S. z siedziba w Nanterre, Francja, RTA GmbH z siedziba w St. Aegyd am Neuwalde, Austria. 


\section{Bibliografia}

\section{Akty prawne}

Rozporządzenie Rady (WE) z dnia 20.01.2004 nr 139/2004 w sprawie kontroli koncentracji przedsiębiorstw (Dz. Urz. 2004, L 24, s. 1).

Ustawa z dnia 15.12.2000 r. o ochronie konkurencji i konsumentów (Dz.U. WE z 2000 r., nr 122, poz. 1319 z późn. zm.).

Ustawa z dnia 17.02.2007 r. o ochronie konkurencji i konsumentów (Dz.U. nr 50, poz. 331, t.j. Dz.U. z 2017 r., poz. 229 z późn. zm. - dalej jako: uokk).

\section{Literatura}

Dudzik S., Kontrola koncentracji w świetle ostatnich zmian ustawowych, iKAR 2015/2 (4).

Gronowski S., Uokk. Komentarz, drugie wydanie, Warszawa 1999.

Gronowski S., Ustawa antymonopolowa. Komentarz, Warszawa 1996.

Joint Ventures. Antitrust Analysis of Collaboration Among Competitors, Second Edition 2014, ABA Section of Antitrust Law, ABA Publishing, Chicago 2014.

Kohutek K., Sieradzka M., Ustawa o ochronie konkurencji i konsumentów. Komentarz, Wolters Kluwer business, Warszawa 2014.

Kokkoris J., Shelansky H., EU Merger Control. A Legal and Economic Analysis, Oxford University Press 2014.

Kostecka-Jurczyk D., Koncentracja w formie wspólnego przedsiębiorstwa a ryzyko konkurencyjne w'świetle prawa antymonopolowego, C.H. Beck, Warszawa 2017.

Kostecka-Jurczyk D., Kontrola koncentracji a nabywanie pakietów mniejszościowych, PPH 2015/12.

Kostecka-Jurczyk D., Kryterium petnego zakresu funkcji w analizie koncentracji w formie joint venture, Finanse, Rynki Finansowe, Ubezpieczenia 2016/82 (4).

Lenart J., Kaczyńska T., Kiedy utworzenie nowej spótki nie będzie kwalifikowane jako utworzenie nowego przedsiębiorcy (joint venture)? Praktyczne rozważania dotyczace problematyki joint venture w polskim prawie konkurencji, iKAR 2016/1 (5).

Materna G., Pojęcie przedsiębiorcy w polskim i europejskim prawie konkurencji, Wolters Kluwer, Warszawa 2009.

Skoczny T., Ustawa o ochronie konkurencji i konsumentów, Komentarz, C.H. Beck, Warszawa 2014.

Stankiewicz R., Joint ventures w prawie antymonopolowym, PPH 2007/8.

Stankiewicz R., Nadzór administracyjnoprawny jako forma relacji określajaca oddziaływanie państwa na procesy koncentracji przedsiębiorców, Studia Iuridica 2006/XLV.

Wenz A., Der Begriff der Kontrolle im europäischen und deutschen Fusionsrecht, Marburg 2007.

\section{Decyzje Komisji Europejskiej}

Decyzja Komisji z dnia 3.10.2008 w sprawie COMP/M.5241 - American Express/Fortis/Alpha Card, pkt 1, 16.

\section{Decyzje Prezesa UOKiK}

Decyzja Prezesa UOKiK z dnia 14.08.2002 nr RKT-41/2002 w sprawie Gmina Dąbrowa Górnicza, „Nemo-Investment” Sp. z o.o. w Czeladzi i „NEMO-WODNY ŚWIAT Dąbrowa Górnicza” Sp. z o.o. w Dąbrowie Górniczej. 
Decyzja Prezesa UOKiK z dnia 30.10.2003 nr DDF-37/2003 w sprawie Orbis S.A. z siedziba w Warszawie i Consulting Plus Sp. z o.o. z siedziba w Warszawie (utworzenie wspólnego przedsiębiorcy: Conbis Sp. z o.o. z siedziba w Warszawie).

Decyzja Prezesa UOKiK z dnia 14.09.2004, DOK-91/2004 w sprawie Schneider Toshiba Inverter SAS z siedziba w Pacy sur Eure, Francja i VA TECH ELIN EBG Elektronik GmbH \& Co. z siedziba w Wiedniu (utworzenie wspólnego przedsiębiorcy: STI ELIN Inverters GmbH z siedziba $w$ Wiedniu).

Decyzja Prezesa UOKiK z dnia 14.05.2007 Nr RKR-44/2007 w sprawie APIA Real Estate S.a.r.l. z siedziba w Luksemburgu i Atrium Residence Sp. z o.o. z siedziba w Krakowie.

Decyzja Prezesa UOKiK z dnia 22.06.2018 nr DKK-102/2018 Faurecia Exhaust International S.A.S. $z$ siedziba w Nanterre, Francja, RTA GmbH z siedziba w St. Aegyd am Neuwalde, Austria.

Inne

Skonsolidowane obwieszczenie Komisji dotyczące kwestii jurysdykcyjnych na mocy rozporządzenia Rady (WE) nr 139/2004 w sprawie kontroli koncentracji przedsiębiorstw, Dz. Urz. 2008, Nr C 95, s. 1, pkt 95 i 98 (dalej jako: obwieszczenie jurysdykcyjne).

Wyjaśnienia w sprawie kryteriów i procedury zgłaszania koncentracji Prezesowi UOKiK, Urząd Ochrony Konkurencji i Konsumentów, Warszawa 2015, https://uokik.gov.pl/download. php?id=1269; stan na 28.09.2019 r..

\title{
Daria KOSTECKA-JURCZYK
}

\section{OBLIGATION TO NOTIFY THE CREATION OF A JOINT VENTURE}

\begin{abstract}
Background: The obligation to notify the creation of a joint venture to the President of the Office of Competition and Consumer Protection (UOKiK) in the light of the provisions of the Act on Competition and Consumer Protection raises numerous interpretation doubts that cannot be resolved by analogy with the principle adopted in Council Regulation (EC) No 139/2004. Both solutions differ significantly.

Research purpose: The study analyzes the obligation to notify in both legal regimes and assess the legitimacy of the solutions adopted in Polish national law. The hypothesis is that the obligation to notify in the light of Polish Act on Competition and Consumer Protection was formulated too broadly. Article 13 para. 2 point 3 of the Act enforces the need to notify about joint undertakings that are not a form of (economic) concentration and is detached from the principle of joint control established in the EU law, which is the necessary condition for determining concentration.

Methods: In order to verify the adopted research hypothesis, an analysis of legal acts, decisions of the European Commission, and the President of UOKiK was conducted. In order to analyse the Council Regulation (EC) No 139/2004 and the Act on Competition and Consumer Protection both formal-dogmatic method of as well as a comparative legal analysis.

Conclusions: It is concluded that the obligation to notify joint venture in Polish Competition Act is formulated too broadly, as it includes joint entrepreneurs whose creation does not in fact meet the conditions for concentration.
\end{abstract}

Keywords: competition law, joint venture, mergers. 